\section{The pathology of history}

\author{
The Deadly Truth: A History of \\ Disease in America \\ Gerald Grob \\ Harvard University Press: 2002. 368 pp. \\ $\$ 35, £ 23.50$, E35
}

\section{W. F. Bynum}

A generation ago, historians discovered the importance of disease in human history. Plagues and Peoples (1976) was written by William H. McNeill, then professor of history at the University of Chicago, who had previously provided admirable synoptic accounts of world history. His book was a revelation, even to medical historians, who were then concerned with doctors rather than patients or disease. Gerald Grob, a distinguished historian of psychiatry and medicine, cites McNeill's book in his own more modest account of disease in American history.

Grob has always been known for his quiet medical realism, even in the problematic field of psychiatric history. This makes his sombre reading of the past, present and probable future history of disease in American society all the more telling. There is no social constructivism here, rather the more convincing historical insight that geography, genetics, behaviour, social perceptions and economic realities have shaped disease realities in the past, and are likely to continue to do so. Indeed, the real guiding light behind Grob's analysis is not McNeill, but the microbiologist René Dubos of the Rockefeller Institute (as it was then called), who told us more than four decades ago that medical utopias are mirages. Dubos would have applauded medical advances since, but his conclusions, I believe, would have been much the same.

As a historian, however, Grob's brief is with the past, not the future. He takes a long view in a short book, from the consequences of European settlement for the health of native Americans, to the age of AIDS and other chronic diseases. He offers several particular insights and three broad themes that are worth pondering.

First, geography (and hence climate) has shaped the history of disease in America. Massachusetts, Virginia and South Carolina posed radically different challenges to the various groups of Europeans who tried to settle there. Hard winters often meant food shortages with attendant nutritional disorders and diseases of overcrowding. The American south had its own health problems, including the insect-borne scourges of malaria and yellow fever. Smallpox was no respecter of climate, although it was a convenient agent in the European struggle with the native inhabitants. Infected blankets were sometimes traded to unsuspecting

\section{Art}

\section{A leap into the future}

How far can science and technology push the frontiers of human sporting achievement? This question occupied New York artist Alexis Rockman during his year-long residency at Camden Arts Centre in London, which has just ended.

The studies shown here for his work in progress, Future Olympics, show the fruits of his long discussions with physiologists and molecular biologists in London and Oxford. They display his signature motif: the grafting together of the artificial and the organic, which has been a hallmark of much of his earlier work.

This style was evident in

Rockman's famous image The Farm, which led to his portrayal as a harbinger of the dangers of genetic engineering. He confesses that his view of science is "confused", believing that science may have caused problems but that it will also help to solve them.

Rockman will take part in 'Superhumans and Superstitions: The Contested Identity of the Human Body', a public panel discussion to be held at the Royal Institution in London on 8 May.

www.rigb.org

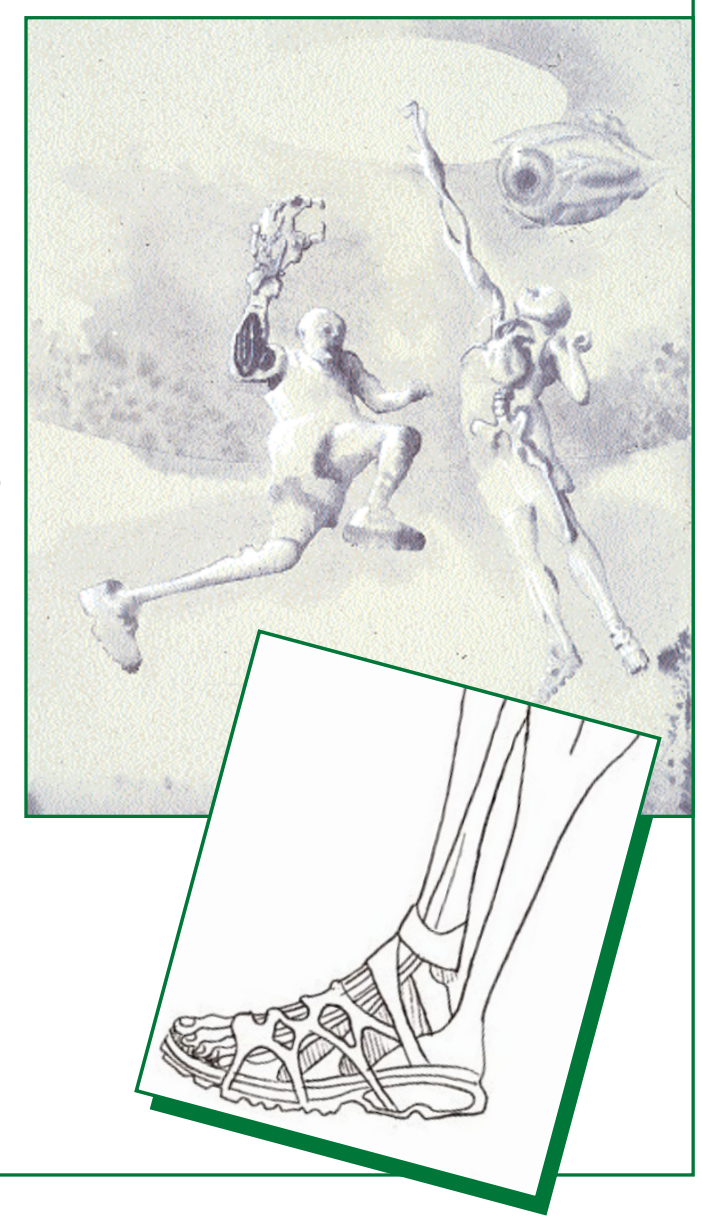

tribes; bioterrorism is no new phenomenon.

The south continued to bear a geographical health burden until well into the twentieth century, but in nineteenth-century America, the cities, wherever they were located, were central to the geography of health. New York, Philadelphia and the other cities on the east coast received the bulk of immigration from Ireland and southern and eastern Europe. Diseases of deprivation and destitution were rife, and sanitary reform was slow and partial. What demographers call the urban penalty relaxed only gradually, and still exists in a variety of forms in cities everywhere.

The second theme of Grob's monograph is the continuing importance of gastrointestinal disorders. Cholera has received a lot of historical attention, but Grob reminds us that dysentery and other diarrhoeal disorders were a far more common cause of morbidity and mortality than the more spectacular cholera epidemics. Infants and children were particularly susceptible to gastrointestinal afflictions, even before the increase in bottle-feeding during the nineteenth century. Like the diseases themselves, the literature on cholera and consumption is more visible historically. But diarrhoea and its consequences caused concern, and historians ought to continue to explore this cluster of diseases.

Grob's final theme is that disease is not about to disappear. His book is properly appreciative of the contributions of modern biomedicine to the health and longevity of Americans and other fortunate citizens of the Western world. But he writes from the sombre perspective of the new millennium, when the problems of modern medicine tend to be more newsworthy than its achievements. Talk about the conquest of acute infectious diseases now seems hollow, and we dwell instead on the chronic ones that have replaced them. A generation ago, Dubos was a prophet crying in the wilderness. Grob is a chronicler of his times.

Grob's achievement is considerable. He has read and synthesized a massive literature on the social history, demography, and medical and cultural experience of a large country. His judgements are judicious and his book deserves the ultimate compliment: it would have been better had it been twice as long. W. F. Bynum is at the Wellcome Trust Centre for the History of Medicine at University College London, 24 Eversholt Street, London NW1 1AD, UK. 